\title{
The Exploration of Public English Teaching reform in Application-oriented colleges
}

\author{
Yan Lisha* \\ Jilin Engineering Normal University \\ Changchun, China \\ e-mail: arnold0110@sina.com \\ * Corresponding Author
}

\author{
Zhang $\mathrm{Na}$ \\ College of Art and Design \\ Shenyang Jianzhu University \\ Shenyang, China
}

\begin{abstract}
As the application-oriented colleges will become the mainstream of the development of higher education, such colleges are shouldering mission for training high-skilled talents for meeting the needs of social production, construction, service and management. Therefore, public English teaching reform is imperative. How to solve the problems and challenges faced by the present stage of public English teaching is perpetual object. The paper attempts to explore English teaching reform in five aspects--teaching target, teaching content, teaching mode, the construction of English teachers' group and the evaluation system through theory of the ESP and the output-driving hypothesis theory in application-oriented colleges.
\end{abstract}

Keywords-application-oriented college; college English teaching model; reform; English comprehensive competence; application-oriented talents

\section{INTRODUCTION}

With the rapid development of Chinese society, higher education becomes more and more popularization, and the application-oriented colleges arises at this historic moment. The purpose of the application-oriented colleges is to meet the needs of regional development with Chinese characteristics, and to cultivate highly applied talents who have strong practical ability and potential for sustainable development to provide the services for local production and construction. It is required that the public English teaching in application-oriented college should be oriented by the social needs and working requirements, aim at cultivating students' English comprehensive competence and help them learn foreign advanced science and technology and make use in the social practice. The traditional college English teaching model is very difficult to adapt to this goal, so the English teaching reform in application-oriented colleges is extremely urgent.

\section{GENERAL REVIEW}

The popularity of higher education in western developed countries is much earlier than in China, and application-oriented college in our country is on the basis of its references. Germany application-oriented colleges has great practical significance to develop our applicationoriented college reform at the present stage. Such colleges require that the graduates not only have strong professional learning and also have broad knowledge, and the curriculum setting is asked to improve the ability of solving practical problems in enterprises or society. Featuring its academic reflection and integrated analysis of community's needs, America put forward "ServiceLeaning" strategy which continues to receive sustained attention from various institutions of higher education[1]. By setting courses which are applied to social service, colleges increase the training of practical ability and conveying knowledge at the same time so as to broke the closed state of the traditional university teaching. The "French University Schools" which differ from the comprehensive university pay more attention to the combination of teaching and practice and its course setting are close to professional practices. In Russia, higher education focuses on the efficiency of college operation to ensure the students training objectives consistent with the the economic and social development prospects. In Japan, college students can choose their majors according to their abilities and talents. They made a lot of reforms in English teaching to abandon spoon-feeding method and pay attention on cultivating students' communicative abilities instead by personalized English teaching, modern technologies, etc. This kind of new English teaching model adapted to the development of science and technology in Japan, the needs of economic development, and also had provided the safeguard for Japanese post-war economic recovery. Thus, higher education in developed countries is part of the society, and the application-oriented colleges must become the mainstream of the development of higher education.

\section{A. The Indefinite Teaching objective}

The English teaching objective in most applicationoriented colleges is still to teach the traditional language knowledge and the appraisal standard is the rate of passing CET-4. However, due to the weak foundation of the students in such colleges, the rate of passing CET-4 is very low. While the contents of traditional English teaching is like dumbo-jumbo for them, it is difficult for the students to understand as they are obscure to most of the students. Even though some of them may pass the CET-4, they still have difficult in English communication, letting alone to apply them. After graduation, they may find that what they have Learned in colleges cannot meet the demands of the working environment in society, and they still have obstacle in English communication when they use.

\section{B. The outdated teaching content}

The outdated teaching content can't match with the progress of the society, and a lot of content that includes the changes of the spoken language, the change of the popular expressions can't keep pace with the times. Many textbooks have been used for ten years, and they are difficult to adapt to the rapid development of today's society. The teaching contents in most application-oriented colleges still pay attention to the interpretation of language 
knowledge which don't have much effect in application. Because of the expansion of college enrollment, most colleges adopt large-class teaching, so most students are lack of language skill practice in classes. As the application-oriented colleges graduates are trained for high-skilled mission in the production, construction, service and management, they don't need profound knowledge of English, but can apply learned knowledge of English to work. Therefore, the language skill training is particularly important for students in application-oriented colleges.

\section{The stereotyped teaching model}

The traditional college English teaching pay more attention to the input of knowledge, rather than the output of knowledge, and the teaching model are stereotyped. They use "teacher-centered" teaching mode as the main body of curriculum teaching, so it cause the students are lack of initiative, they are bystanders rather than the real participants. They pay attention to the teacher's teaching rather than the students' learning by using a blackboard. As the society's progress, some colleges also refer to the multimedia teaching, but the classes are still dominated by the teachers, and it is hard for students to be really involved in it. Teacher in the classes are likely to analyze some key words and grammars, translate the text, and conclude the language points by doing some exercises of the textbooks. Such cramming teaching mode mainly focuses on language points, but students have no reflection on the knowledge they have learned, letting alone to apply them freely.

However, application-oriented colleges education must focus on market and social requirement to train higher technology applied talents for working at first line of production, construction, management and service. Such teaching mode is hard to meet the demands of that requirement, and it is difficult to achieve this goal only by improving the classroom teaching. Many colleges have reduced public courses hours, but haven't added practical public teaching courses so that the teaching effect is even more difficult to achieve. They only open college English intensive reading courses, with no specialized courses on English writing, oral English, listening etc. The elective courses on English is very few, and there are few English activities in such colleges, such as English contest and festival. Even though we have some English contest, they only focus on the language knowledge instead of English comprehensive competence. This lead to the final effect of college English teaching can't make the national demands for the talent training in application-oriented colleges.

\section{The deficient teaching staff}

With the college enrollment expansion, the teacherstudent ratio is decreasing from 1:50 in 1998 to 1: 130 in 2001 according to the survey of Wang Shouren[2]. The the average age of English teachers are low, and most of them have undergraduate degree, some have master degree, rather few have doctoral degree in applicationoriented colleges. In recent years, with the continuous development of English teaching reform, the English teaching staff have been strengthened and the teachers' qualities have been greatly improved. While the English teachers are still lack of the opportunities to study abroad and take part in straining and meetings, which is great developing poverty to the English teachers. Most teachers have carried a lot of English teaching workload due to the enrollment expansion, which make them have less time to make research on teaching. They are lacking of linguistics, applied linguistics and other related knowledge as well as advanced teaching concept, and a small amount of linguistics theory is difficult to be used to guide the teaching. Among the English teaching staff in applicationoriented colleges, very few are double-certificated teachers which is highly advocated by the government. So most teachers can only teach English language knowledge without of teaching English for special purpose like business, art ,engineering etc. Thus, it is hard to satisfied the purpose of cultivating the students' ability, who will be engaged in the production, construction, management and services. Application-oriented colleges lack complete English teaching team, and the construction of English teachers' team is the key to the construction of the course reform, and provides the important guarantee to improve the level of the English teaching quality.

\section{E. The imperfect evaluation system}

The traditional evaluation system is given great priority to the examination with the regular grades as supplementary, and the majority of colleges final exam scores are accounted for more than $70 \%$ of the exam paper. Thus, it is clear that the assessment system focuses on the cultivation of English language knowledge and ignores the English practical skills, which means ignoring the practicability of the English. At the same time, the content of the exams is given priority to the vocabulary, grammars, and reading, ignoring the assessment on spoken English, listening comprehension, translation and writing. Therefore, it is difficult to meet the needs of training the application-oriented talents.

\section{THEORY BASIS}

\section{A. "output-driving hypothesis"}

Output-driving hypothesis is promoted by Wen Qiufang based on the actual situation of China's English teaching. She have analyzed the practical English function in workplace use and the psychological mechanism of second language acquisition and output so as to construct this theory. "Output-driving hypothesis", hypothesis theory of second language teaching, promote the output of listening, speaking, reading and writing by input of teaching[3].

The output driver and input formation is the integration of the output and input. It improves supply and a new way of thinking of public foreign language teaching in application-oriented colleges.

\section{B. The theory of ESP}

ESP originates Greek and Rome times. Take the second World War as example, it elucidates ESP was popular at that time. In order to understand Japanese warplane's wireless disco use, the Royal Army's officials were in need of Jangles listening training and a few constabulary training. After the second world war, the environment was peaceful, the language for special purpose, especially the ESP developed well. Hutchinson and Waters deem that is because of the need of after-war's international political and economic development. 
In the modern society of China, the spread of ESP is enlarging. because the American and English' economy booming, English becomes the international lingual franc a. Japan is ASL a country makes full use of ESP. English turns to be Lingual Fran ca because of information revolution and international integration. English is applied to International Aviation, telecommute, traveling, sports events, chronology communication and business trade. In the information era, ESP is pushed into a new height, the computer science is popular and it leads to the spreading of ESP internationally.

ESP teaching is based on the major's need practical English teaching. By ESP, the students are fostered to their impotency career field. They can communicate more correctly and more efficient compared with those who only accept normal English teaching.

\section{EXPLORATION OF ENGLISH TEACHING REFORM}

\section{A. Teaching objectives}

The Plan Outline of the National Medium and Longterm Education Reform and Development (2010-2020) put forward expanding the opening of education, adhering to the open for facilitation of the reform and the concept of development[4]. At the same time, Outline put forward the guidelines that the communication and cooperation of education should be broadened to various fields with different layers; the national internationalization of education should be enhanced. English teaching of application-oriented must meet all international graduates' practical study, employment requirement and the new environment brought by the development of modern technology. In order to set standards of different public English teaching objectives for the various types of applied undergraduate colleges according to the society' $\mathrm{s}$ needs, careful analyses on the position and function of applied undergraduate colleges' talents are priorities. Applies undergraduates' English teaching should aim for: according to the professional development needs, foster the students basic linguistic skills in English and the application ability of their major, especially the English reading, listening ability and certain writing and translation ability. As a result, they can obtain the effective English linguistic materials and improve their autonomous learning ability. They can understand the western and eastern cultural differences to multiple their competition ability in the global view.

\section{B. Teaching content}

In order to train Hi-tech field talents to production, construction, service and management, the selection of the teaching content should be social need oriented. The former English teaching content is for passing CET4 and CET6, neglecting the society' s real demands. The testbased teaching content is hard to meet the society' $\mathrm{s}$ needs, so the application should be primary in choosing the teaching content.

Textbooks and course book should be changed from the traditional single teaching contents, into a diversified teaching content, which can be divided into the single teaching different skills and cultivate the cultivation of communicative ability, writing, translation ability, in order make them to practice what they learn. At the same time, for different major, there should be different ESP teaching contents, such as engineering English, art English,business English,etc. A lot of applied undergraduate colleges and universities student's English deficiencies is uneven, for this phenomenon, we can not ignore the individual differences. According to their aptitude, the content of the teaching for students of different levels should adopt different teaching contents.

At the same time, in order to stimulate the students enthusiasm of English learning, newly invented network words and recent heat discussed topics should be integrated into the class.

\section{Teaching model}

The Course Requirements mentioned that universities make full use of modern information technology, based on the computer and the classroom English teaching mode, improvement is given priority to with the teacher taught a single teaching mode. The new teaching pattern should take the modern information technology, especially network technology as the support, and make the teaching and learning of English in a certain extent, not limited by time and place, the direction of individualized and autonomous learning the essence of this teaching mode is "information-based teaching mode", but we can't single use only information-based teaching mode. Students get lost in the flow of information without the instructions from teachers.

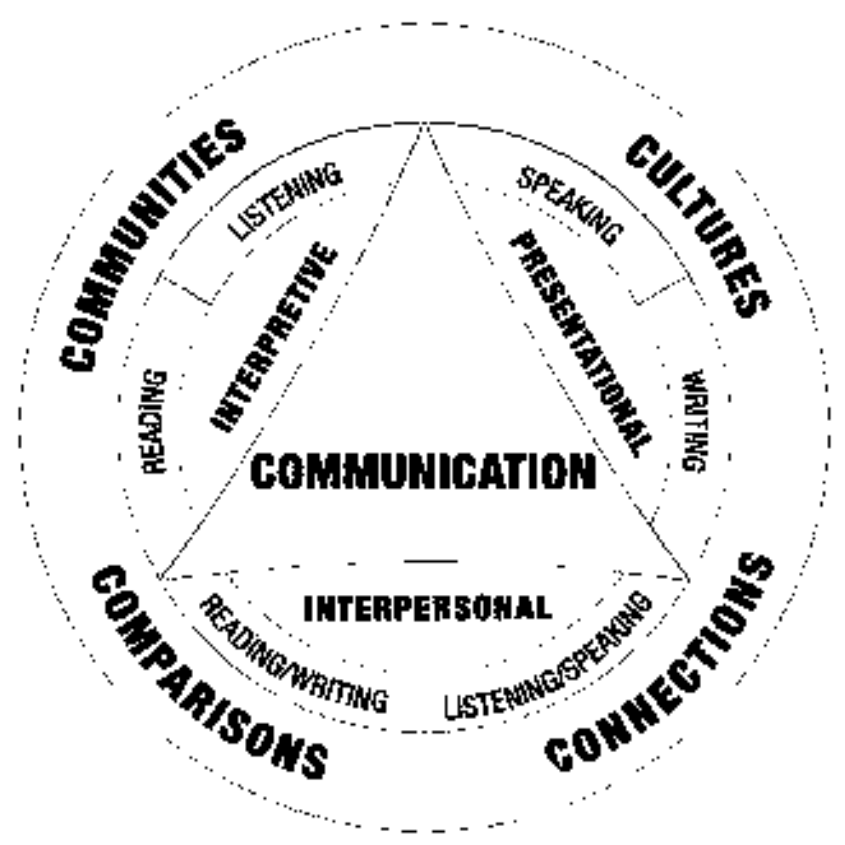

Figure 1. example of English teaching mode

Furthermore, at this stage we should promote the diversification and three-dimensional teaching mode, advocating the application-oriented multiple resources, interesting class and varied multidimensional teaching methods. As is shown in Figureq1, we could see that the communication should contribute to the Elisha skillslistening, speaking, writing, reading etc so as to cultivate the students communicative competence and cultural awareness. The students are given more time to practice their English knowledge, such as taking part in the 
English skills Contest and communicate with native speakers orally.

\section{The construction of English teacher group}

The construction of English teachers' group in application-oriented colleges should adapt to the development of English, and the target should be constructing a social competitive team. At the same time, we should also vigorously develop the construction of double-qualified teaching group. At the same time, English teachers should be given more opportunities and time to study and more training opportunities, and let them step out of the classroom to go out to see the demands of the society. Reform of the teachers group is a serious topic, as teachers also need to learn, explore and research in practice. The demands of the construction of teachers is to cultivate application-oriented talents, and is also a key of the reform of application-oriented colleges.

\section{E. The evaluation system}

We should change the traditional single predominantly examination evaluation system, to carry out multiple evaluation system is to cultivate students English comprehensive application ability, and it is the basis of strengthening the independent learning ability and the demands for training application-oriented talents. The diversified evaluation should be a combination of formative evaluation and summation evaluation. The summation evaluation is given priority to the final exam, while formative assessment contains the classroom teaching activities, and practice class activities, such as competition, network classroom, etc. The multiple evaluation system helps to examine students' English skill learning, mobilize students' learning English at the same time, also help students' long-term development, and is an important part of applied English teaching reform.

\section{CONCLUSION}

To sum up, English teaching reform in applicationoriented colleges is imperative, and such colleges are shouldering mission for training high-skilled talents for meeting the needs of production, construction, service and management. To be given priority to the social needs of the reform of public English, we should change the mute English and cramming teaching mode, and construct a new diversified comprehensive teaching model, which is of crucial importance.

\section{REFERENCES}

[1] G. Eason, B. Noble, and I. N. Sneddon, "On certain integrals of Lipschitz-Hankel type involving products of Bessel functions," Phil. Trans. Roy. Soc. London, vol. A247, pp. 529-551, April 1955. (references)Battistoni, R.M. Civic engagement across the curriculum: A resource book for service-learning faculty in all disciplines [M]. Providence, RI: Campus Compact, 2002.

[2] Battistoni, R.M. Civic Engagement Across the Curriculum: A Resource Book for Service-learning Faculty in all Disciplines [M]. Providence, RI: Campus Compact, 2002.

[3] Wang Shouren. Develop Report of Foreign Language Education in Colleges, $[\mathrm{M}]$ Shanghai: Shanghai Foreign Language Education Express. pp. 71-72.

[4] Wen Qiufang. Output-driving hypothesis in Enlish major skills [J].

[5] Foreign Language, 2008:2-9

[6] National Ministry of Education. National Medium and Long term plan for Education Reform and Development.(20102012)[Z].Beijing: People Rress, 2010.

[7] National Ministry of Education. College English Curriculum Requirements,[Z]. Beijing:Foreign Language Teaching and Research Press, 2007.

[8] Brown, J.D. The Elements of Language Curriculum: A Systematic Approach to Program Development.[M].Beijing: Foreign Language Teaching and Research Press,2001

[9] Richards, J.C. Curriculum Development in Language Teaching [M].Foreign Language Teaching and Research Press \&Cambridge University Press, 2008.

[10] Davies, P. \& Pearse, E. Success in English Teaching [M]. Oxford: Oxford University Press, 2000.

[11] Dörnyei, Z. Motivation and motivating in the foreign language classroom [J]. The Modern Language Journal, 2009, 273-284.

[12] Eccles, J. S., Wigfield, A. Motivational beliefs, values, and goals [J]. Annual Review of Psychology, 2008:109-132.

[13] A. R. Jr. A review of the motivated strategies for learning questionnaire [DB/OL], 2005. 